\title{
Biosensors-on-Chip: An Up-to-Date Review
}

\author{
Cristina Chircov ${ }^{1}\left(\mathbb{D}\right.$, Alexandra Cătălina Bîrcă ${ }^{1}$, Alexandru Mihai Grumezescu ${ }^{1,2, *}$ (1) \\ and Ecaterina Andronescu ${ }^{1}$ (b)
}

1 Department of Science and Engineering of Oxide Materials and Nanomaterials, University Politehnica of Bucharest, 011061 Bucharest, Romania; cristina.chircov@yahoo.com (C.C.); ada_birca@yahoo.com (A.C.B.); ecaterina.andronescu@upb.ro (E.A.)

2 Research Institute of the University of Bucharest-ICUB, University of Bucharest, 050657 Bucharest, Romania

* Correspondence: grumezescu@yahoo.com; Tel.: +40-21-318-1000

Academic Editors: Jacek Ryl and Robert Bogdanowicz

Received: 24 November 2020; Accepted: 16 December 2020; Published: 18 December 2020

\begin{abstract}
Generally, biosensors are designed to translate physical, chemical, or biological events into measurable signals, thus offering qualitative and/or quantitative information regarding the target analytes. While the biosensor field has received considerable scientific interest, integrating this technology with microfluidics could further bring significant improvements in terms of sensitivity and specificity, resolution, automation, throughput, reproducibility, reliability, and accuracy. In this manner, biosensors-on-chip $(\mathrm{BoC})$ could represent the bridging gap between diagnostics in central laboratories and diagnostics at the patient bedside, bringing substantial advancements in point-of-care (PoC) diagnostic applications. In this context, the aim of this manuscript is to provide an up-to-date overview of BoC system development and their most recent application towards the diagnosis of cancer, infectious diseases, and neurodegenerative disorders.
\end{abstract}

Keywords: biosensors on a chip; biosensors; microfluidics; point-of-care; diagnostics

\section{Introduction}

As defined by the International Union of Pure and Applied Chemistry (IUPAC), a biosensor is "a self-contained integrated device which is capable of providing specific quantitative or semiquantitative analytical instrumentation using a biological recognition element (biochemical receptor) which is in direct spatial contact with a transducer element". Generally, biosensors are designed to translate physical, chemical, or biological events into measurable signals [1,2]. In this regard, there are three main components within a biosensor, namely the bioreceptor consisting of biomolecules, such as enzymes, proteins, nucleic acids, aptamers, antibodies, organelles, microorganisms, or cell receptors, responsible for the selectivity towards the target analyte, the transducer, such as optical, electrochemical, physicochemical, piezoelectric, mechanical, or thermal, that converts the biorecognition event proportional to the target analyte concentration into a quantifiable electrical signal, and the electronic system, comprising an amplifier, a processor, and a display unit, that will further process the signal into a user-friendly visualization (Figure 1) [3-8].

The multidisciplinary nature of biosensors, involving biology, physics, chemistry, electronics, instrumentation, and economics, has led to an alliance among the experts within the different fields for bridging the gap between academic research and commercially viable products $[6,9,10]$. Therefore, biosensors have been developed for a wide variety of applications within the medical, environmental, pharmaceutical, and food fields (Figure 2) [5], namely for drug improvement, nutrition safety by detecting drugs and toxins in food, or ecology measuring and monitoring by detecting pollutants, microorganisms, or hazardous chemicals in water or soil $[6,11]$. However, the biosensor arena is rapidly 
expanding, especially within the healthcare system, because of their immense potential for medical diagnostics [11-14].

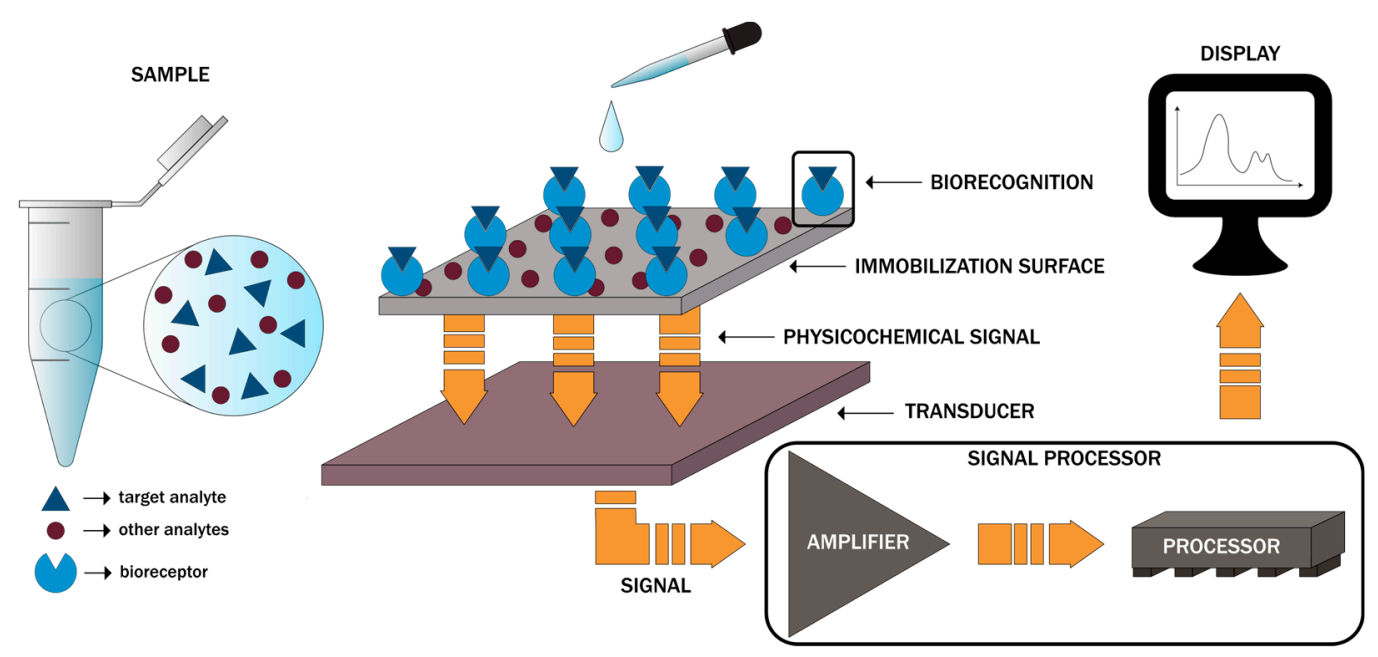

Figure 1. The main components of biosensors and the basic working principle.

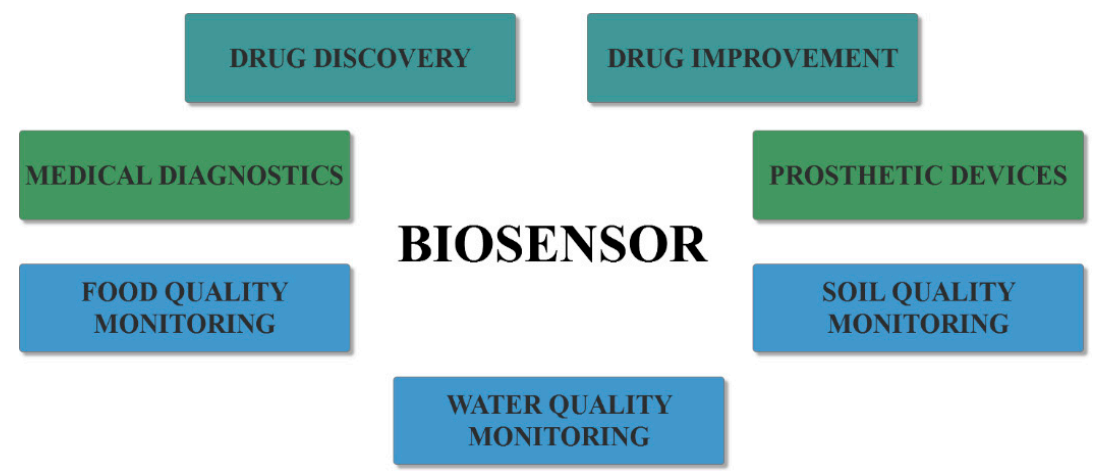

Figure 2. The main applications of biosensors.

While any biosensor is characterized by several advantages and disadvantages based on the targeted application, their design generally involves high ligand specificity and selectivity, high-throughput capacity, dynamic range, rapid detection, ease of engineering and operating, cost-efficiency, and low power requirements [14-16]. However, further improvements for developing ultrasensitive assays capable of single-molecule detection are required [17-19]. In this regard, combining biosensor technologies with microfluidics and nanotechnology could offer the means for the accurate and timely diagnosis of various diseases [20]. Microfluidics, which aims to spatially and temporally control fluids within microscaled systems [21], is the research field with significant applicability in quantitative and qualitative analyses of biological and chemical entities [22,23]. Through its capacity of accurately manipulating small volumes of samples and its highly controlled environments, molecules within the sample rapidly achieve measurable concentrations, thus enabling rapid detection and scaling through parallelization, reduced costs due to lower sample, reagent, and power consumption, and high processing [22-25]. Hence, by integrating biosensors with microfluidic technologies, biosensor-on-chip (BoC) systems with higher detection sensitivity and specificity, resolution, automation, throughput, reproducibility, reliability, and accuracy could be achieved [25-33]. Moreover, microfluidic platforms improve reagent mixing, as it provides reaction chambers for the loading and immobilization of biorecognition elements, thus allowing bioreaction initiation followed by the delivery to the transducer [30]. Thus, the advantages of BoC systems has led to substantial advancements in point-of-care (PoC) diagnostic applications [29], including cancer, a neurodegenerative disorder, and infectious disease diagnosis [34]. Such devices could bring 
significant improvements, especially in the resource-limited environment of the developing countries, as it has brought diagnostics out of central laboratories to the patient bedside [35-37].

In this context, the aim of this paper is to provide an overview of $\mathrm{BoC}$ system development and their most recent application towards the diagnosis of cancer, infectious diseases, and neurodegenerative disorders, thus emphasizing their potential as the future of medical diagnostics.

\section{Design and Working Principles}

BoC systems are based on micro-total analysis systems, which aim to provide complete analytical microscaled systems by diminishing and accumulating all steps required for sample analysis within a single device $[26,38]$. Specifically, it must allow the performance of standard laboratory functions, including sample injection, mixing, reaction, separation, and enrichment, and analyte detection [26,38-40]. Therefore, such systems may contain a variety of units, and their design is generally not straightforward [41,42], as they can function based on passive, active, or hybrid mechanisms. However, the experimental setup commonly involves four main modules: namely, the inlet unit, through which the sample is injected into the microchip; the reacting unit, where the required reactions occur; the analysis unit, where physicochemical reactions are detected by the biosensors; and the data processing unit, where the resulted signals are converted into output signals. Additionally, other modules, such as conditioning or amplification units, could also be introduced when necessary [42]. Furthermore, BoC systems should contain the main components necessary for fluid control and operation and chemical processes, such as microchannels, micropumps, microvalves, and micromixers $[26,39,42,43]$.

Fluids are introduced into the microfluidic device via separate inlets and delivered into the microchannels, subsequently creating concentration gradients [27]. In this context, there are two types of inlets, namely vertical or top-loading inlets, where the loading tube is perpendicularly inserted, allowing for an easier fabrication due to increased compatibility with multilayered geometries, and parallel or in-line inlets, where the tube is parallelly introduced into the microchip [44].

Furthermore, micropumps and microvalves are key components for microfluidics-based analytical systems, especially in multi-step chemical reactions and quantitative analyses, as they enable complex biochemical assay automation $[45,46]$. On the one hand, micropumps are an integral part of microfluidic systems, as they allow for the precise, accurate, and reliable control of fluid transport through the device $[45,47,48]$. Moreover, they are capable of transferring fixed amounts of the fluid to the reaction unit for undergoing mixing, separation, or sensing processes [49]. The necessity of these micro-components has led to the development of various pumping techniques, which involve electrodes, valves, piezoelectric materials, or acoustic transducers introduction and consequently higher costs [48]. Additionally, since active micropumps require external energy supplies, which make them unsuitable for PoC applications, passive micropumps, which circumvent limitations related to power consumption, actuation mechanism integration, and pulsating or oscillating flows, are preferred for $\mathrm{BoC}$ development $[47,48]$. Among them, pneumatic-driven micropumps, which use compressed air for fluid driving, are the most commonly used [45]. On the other hand, microvalves are also fundamental for microfluidic systems, as their functions involve flow regulation, biomolecule, nanoparticle, or reagents isolation, and on/off switching [43,50]. General properties of microvalves include limited leakage, linear operation, small dead volume, insensitivity towards contamination, fast response, and low power consumption [43]. Their performance is directly influenced by structure and geometry, which should be designed for large-scale integration, minimized force for fluid control, portability, and energy efficiency [51]. Besides the general classification into active and passive microvalves, they can also be divided into normally open and normally closed [43]. Among them, the most widely used is the pressure-driven valve, where the membrane deformation leads to the pinch off or opening of the flow channel [46].

As they directly impact BoC efficiency and sensitivity, micromixers are one of the most fundamental components. By contrast to macroscaled fluidic devices, where fluid mixing occurs due 
to convection effects, microscale mixing generally involves external turbulences and/or microstructure integration [40]. Specifically, fluid flow within microfluidic devices is laminar with a Reynolds number lower than 1. Therefore, fluid flow rates are very low and in parallel layers, without disruption between layers. Consequently, fluid mixing depends on molecular diffusion, which is considerably inefficient $[27,40]$. In this manner, by integrating passive or active mixers, the slow mixing challenge can be overcome [27,52]. Passive micromixers are more economical and convenient, as the mixing occurs through molecular diffusion and chaotic advection with no external energy sources [52,53]. Chaotic advection is highly efficient at low Reynold numbers owing to the stream splitting, stretching, folding, or breaking up [54]. Moreover, it is generally achieved through microchannel geometry modifications in order to reduce diffusion length and increase interfacial area [27,53], subsequently causing pressure and velocity variations [54].

While simple microfluidic devices can be fabricated from any type of material, the properties of the selected materials will substantially impact the success of the device, as they directly influence its properties, overall performance, and applicability range $[46,55]$. Specifically, the material is involved in electrical conduction, heat transfer, light transmission, or mechanical transduction, and it influences the fluid physical behavior and constitution [55]. Additionally, the biocompatibility and wettability of the device are dependent upon the material choice and the microfabrication technique [41]. The most common materials used for microfluidic device development include glass, silicon, and thermoplastic or elastomeric polymers, such as polymethylmethacrylate (PMMA), polydimethylsiloxane (PDMS), and polycarbonate, owing to their cost-efficiency, biocompatibility, suitable physicochemical and mechanical properties, and ease of manufacturing [41,46,56].

However, recent years have witnessed a tremendous scientific interest in using paper as a material for microfluidic applications [57,58]. As cellulose is the basic component, the paper is a thin, light, and hydrophilic material, which allows for the spontaneous infiltration of water without requiring additional pumps [57]. Additionally, the paper is highly advantageous for BoC systems and PoC assays owing to its versatility, availability, and flexibility, allowing for the manufacture of portable, disposable, easy to operate, and cost-efficient devices [57,59,60]. Moreover, it can be chemically functionalized in order to design hydrophobic barriers for the spatially resolved transport of fluid [57,58]. However, there are still some issues related to the use of paper, such as the geometric and chemical complexity of the material and the imprecision associated with most paper patterning methods, which have considerably limited its applications $[58,60]$.

Nonetheless, biosensor performance is significantly influenced by the amount, spacing, and stability of the surface-immobilized bioreceptors within the BoC device [61]. Therefore, additional strategies for modifying their surface properties are often required [55]. In this context, after their surface functionalization with reactive functional groups, nanomaterials allow for the attachment of various biomolecules, such as antibodies, protein receptors, or peptides, in order to develop multifunctional materials for targeted treatment and diagnostics [62]. Owing to their small size and high surface areas, nanomaterials have revolutionized both the electrochemistry and electroanalysis fields, as they can be used for the detection of target analytes within extremely low-concentration solutions $[62,63]$. In addition, nanomaterials possess strong adsorption capacity and reduced non-specific adsorption due to abundant binding points, high conductivity, high passivation resistance, enhanced catalytic activity, and biocompatibility [20,61,63]. Therefore, the incorporation of nanomaterial-based biosensors within BoC systems has become a widely employed strategy for enhancing analytical performances (Figure 3) [61,63]. In this manner, the sensitivity, selectivity, stability, capture efficiency, and reproducibility of BoC are significantly improved [20,61,63,64]. However, the immobilization of the nanomaterial-based biosensors should allow for the proper orientation of the biorecognition molecules for target recognition and avoid its deterioration or leakage. Thus, atomic layer deposition is one of the most promising techniques used for the precise deposition of thin nanomaterial layers onto the surface, ensuring both conformality and uniformity for immobilization [20]. There have been many studies regarding the use of nanomaterials for BoC development, including 
carbon and metallic nanoparticles, nanobeads, nanotubes, nanowires, nanofibers, nanopillars, and nanohorns [20,63,64]. Additionally, graphene-based two-dimensional nanostructures have also attracted a great scientific interest in the recent years $[63,64]$.

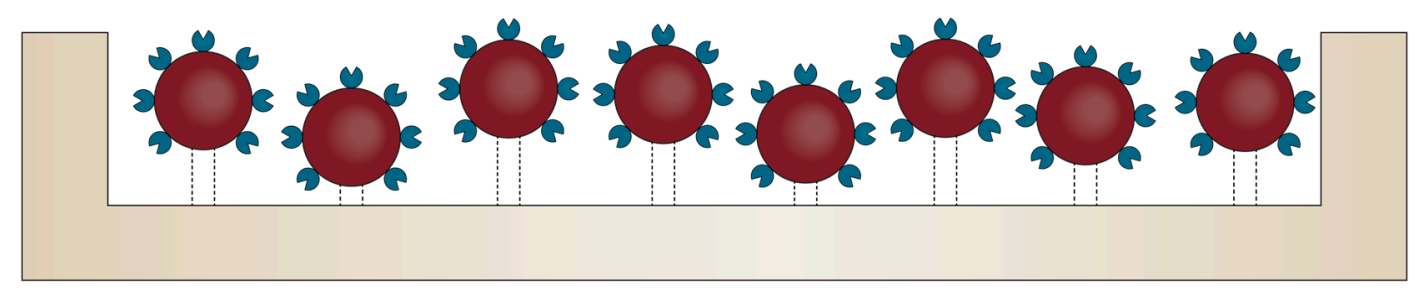

Figure 3. Schematic representation of the use of bioreceptor-functionalized nanomaterials deposited onto the surface of the microfluidic chip.

Furthermore, the combination of nanomaterials with microfluidics and modern optical sensing techniques has led to the emergence of a novel and rapidly growing interdisciplinary research field, namely optofluidics $[65,66]$, which has significantly increased detection sensitivity and reduced the detection limit for various biosensors [67]. The surface-enhanced Raman spectroscopy (SERS) is an ideal example of a detection method that has considerably benefitted from the integration of optical nanosensors within microfluidic devices [68,69].

\section{Diagnostic Applications}

\subsection{Cancer Diagnosis}

Solid tissue biopsies remain the gold standard for tumor confirmation, diagnosis, and classification, consisting of tumor tissue removal and subsequent histopathological and cytological examination. Nevertheless, the procedure is highly painful and invasive. It further induces the risk of bleeding, inflammation, and malignant cell dissemination. Additionally, the amount of the extracted sample is generally insufficient. The spatial and temporal heterogeneity of the tumor tissue might lead to inconclusive results $[70,71]$. However, tumor tissues shed into the body fluids a variety of components, including cells, nucleic acids, proteins, or exosomes, which could serve as tumor biomarkers that provide similar information to tissue biopsies [70]. In this context, liquid or fluid biopsies have emerged as a term defining the set of diagnostic procedures using cancer-derived materials from body fluids [71,72]. This technique has provided a promising alternative to traditional biopsies due to the minimal invasiveness, cost-efficiency, and possibility of sampling at any time points during therapy to assess disease progression $[70,71]$.

Although liquid biopsies can be sampled from any body fluid, blood is the most widely used as it allows for the detection of most cancer types, by contrast to urine or saliva, which are used for the detection of specific types. Nonetheless, the use of blood samples is still challenging due to the presence of countless cells and molecules, which makes the assessment of extremely low quantities of biomarkers difficult [71]. In this regard, the development of sensitive platforms able to routinely detect and quantify reduced levels of biomarkers within body fluids represents the means for enabling personalized medicine in cancer therapy [70]. Microfluidics-based technologies represent a promising solution in this field. There is a great scientific focus towards developing biosensor-integrated microfluidic chips for cancer diagnosis [70,71,73].

In this context, the process of paper selection for reviewing involved a literature survey using the Scopus database and the keywords "microfluidic (bio)sensor" and "cancer diagnosis". A series of 17 potential papers published since 2018 related to the subject were identified. All papers are summarized in Table 1 and described in the following paragraphs. 
Table 1. A summary of the identified papers investigating the use of microfluidic biosensors for cancer diagnosis.

\begin{tabular}{|c|c|c|c|c|c|c|c|}
\hline Biomarker Type & Biosensor Type & $\begin{array}{l}\text { Measuring } \\
\text { Principle }\end{array}$ & Target & Capture Molecule & Cancer Model & $\begin{array}{l}\text { Limit of } \\
\text { Detection }\end{array}$ & Ref \\
\hline \multirow{6}{*}{ CTCs } & immunosensor & fluorometry & ЕрСАМ & EpCAM antibody & MCF-7 breast cancer cells & n.r. & [74] \\
\hline & immunosensor & fluorometry & EpCAM & EpCAM antibody & $\begin{array}{l}\text { EJ138, HT1376, HT1197, and } \\
\text { RT4 human bladder cancer cells }\end{array}$ & n.r. & [75] \\
\hline & aptasensor & $\begin{array}{l}\text { electrochemical } \\
\text { impedance }\end{array}$ & A549 cells & DNA aptamer & $\begin{array}{c}\text { A549 human lung carcinoma } \\
\text { cells }\end{array}$ & $\begin{array}{l}1.5 \times 10^{4} \\
\text { cells } / \mathrm{mL}\end{array}$ & [76] \\
\hline & immunosensor & $\begin{array}{l}\text { electrochemical } \\
\text { impedance }\end{array}$ & MC1R & MC1R antibody & $\begin{array}{l}\text { SK-MEL-2 human melanoma } \\
\text { cells }\end{array}$ & 10 cells $/ 10 \mathrm{~mL}$ & [77] \\
\hline & aptasensor & fluorometry & miRNA-1246-TAMRA & 3-aminopropyltrimethoxysilane & non-small cell lung cancer & n.r. & [78] \\
\hline & aptasensor & amperometry & miRNA-197 & $\begin{array}{c}\text { complementary single-stranded } \\
\text { DNA }\end{array}$ & - & $1.28 \mathrm{nM}$ & [79] \\
\hline \multirow[t]{4}{*}{ miRNA } & aptasensor & colorimetry & miRNA-21 & $\begin{array}{c}\text { complementary single-stranded } \\
\text { DNA }\end{array}$ & - & $4.1 \mathrm{pM}$ & [80] \\
\hline & aptasensor & fluorometry & miRNA-21 & $\begin{array}{l}\text { thiol-modified hairpin DNA } \\
\text { probe }\end{array}$ & MCF-7 breast cancer cells & $0.0033 \mathrm{fM}$ & [81] \\
\hline & $\begin{array}{l}\text { enzyme-based } \\
\text { sensor }\end{array}$ & chronoamperometry & $\begin{array}{c}\text { miRNA-19b and } \\
\text { miRNA-20a }\end{array}$ & Cas13a effector & brain cancer & $10 \mathrm{pM}$ & [82] \\
\hline & aptasensor & chronoamperometry & $\begin{array}{l}\text { BRCA1, BRCA2, and p53 } \\
\text { breast cancer genes }\end{array}$ & $\begin{array}{l}\text { thiolated 19-mer BRCA1, } \\
\text { 17-mer BRCA2, and 17-mer p53 }\end{array}$ & breast cancer & - & [83] \\
\hline \multirow[t]{5}{*}{ DNA } & aptasensor & SERS & KRAS gene & molecular beacon probes & MDA-MB-435 and SW480 & $50 \mathrm{fM}$ & [84] \\
\hline & aptasensor & SERS & KRAS gene & molecular beacon probes & colorectal cancer & $10 \mathrm{fM}$ & [85] \\
\hline & immunosensor & reflectometry & ErbB2 gene & anti-ErbB2 antibody & breast cancer & $0.7 \mathrm{ng} / \mathrm{mL}$ & [86] \\
\hline & immunosensor & chronoamperometry & CA 125 & CA 125 antibody & ovarian cancer & $0.78 \mathrm{U} / \mathrm{mL}$ & [87] \\
\hline & immunosensor & $\begin{array}{l}\text { capacitance } \\
\text { measurement }\end{array}$ & CA 125 & CA 125 antibody & ovarian cancer & - & [88] \\
\hline \multirow[t]{3}{*}{ proteins } & immunosensor & SERS & $\begin{array}{c}\text { CA 125, CA 153, } \\
\text { carcinoembryonic antigen }\end{array}$ & $\begin{array}{c}\text { CA 125, CA 153, } \\
\text { carcinoembryonic antigen } \\
\text { antibodies }\end{array}$ & breast cancer & $0.0001 \mathrm{U} / \mathrm{mL}$ & [89] \\
\hline & immunosensor & SERS & prostate specific antigen & $\begin{array}{c}\text { prostate specific antigen } \\
\text { antibody }\end{array}$ & prostate cancer & $0.01 \mathrm{ng} / \mathrm{mL}$ & [90] \\
\hline & immunosensor & fluorometry & $\begin{array}{c}\alpha \text {-fetoprotein and } \\
\text { carcinoembryonic antigen }\end{array}$ & $\begin{array}{c}\alpha \text {-fetoprotein and } \\
\text { carcinoembryonic antibodies }\end{array}$ & - & $\begin{array}{l}1 \mathrm{pg} / \mathrm{mL} \text { and } \\
100 \mathrm{fg} / \mathrm{mL}\end{array}$ & [91] \\
\hline
\end{tabular}
n.r.-not reported in the paper. 
Ever since their discovery, the detection of circulating tumor cells (CTCs) within liquid biopsies has attracted significant interest as a tool for early cancer diagnosis, metastatic cancer stage and cancer progression monitoring, and therapy response [92,93]. Microfluidic devices for CTCs analyses focus on cell isolation, detection, and examination, demonstrating a high efficiency, selectivity, and reactivity with reduced sample and reagent amounts and increased fluid control [71,92]. Most studies on the matter focus on isolating CTCs through immunoaffinity, which involves the immobilization of specific antibodies on the surface of the microchannels. Specifically, as it is overexpressed in most cancer types, the epithelial cell adhesion molecule (EpCAM) represents the target antigen in most assays [71,92]. However, strategies for isolating CTCs can also rely on the physical properties changes that occur due to abnormal metabolism and modifications of intracellular substance composition, gene expression, and protein synthesis and aggregation [71,94]. Thus, there are several microfluidic devices developed for the isolation of CTCs based on modifications within their size, density, morphology, stiffness, electrical charge, and dielectric properties [71,94-96]. Such label-free microfluidic methods include magnetic-, acoustic-, dielectrophoresis-, and passive microfluidic-based techniques [97]. Moreover, CTCs separation can be performed through positive or negative enrichment, involving the specific isolation of CTCs within the sample or the separation of all other cells except CTCs from the sample, respectively [71].

In this regard, Çetin et al. developed a gold microfluidic device consisting of a self-assembled monolayer formed onto the surface. The molecules used for the monolayer include cysteamine, 4-aminothiophenol, 3-mercaptopropionic acid, 11-amino-1-undecanethiol, and 11-mercaptoundecanoic acid, which had both amino and carboxylic free functional groups for the subsequent attachment of EpCAM antibodies through both covalent bonding via the carbodiimide crosslinking method and bioaffinity-based immobilization using streptavidin and biotinylated EpCAM. MCF-7 breast cancer cells were used as the CTCs model, while K562 leukemia cells were used as an EpCAM-negative model. Results showed that the presence of the aromatic ring in the within alkanethiols allowed for intermolecular interactions and consequently increased cell capture events. Additionally, covalent bonding permitted high flow rates within the microchannels, with negligible numbers of detached cells [74]. Furthermore, Chan et al. investigated the efficiency of PMMA microfluidic channels coated with EpCAM antibodies-immobilized polyoxazoline polymer through covalent bonds for the photodynamic identification of EJ138, HT1376, HT1197, and RT4 human bladder cancer cells treated with protoporphyrin IX. Their findings showed that hexaminolevulinate-induced fluorescence increased substantially in cancer cells, with optimal discrimination achieved for cells in suspension after incubation at $50 \mu \mathrm{M}$ hexaminolevulinate for $2 \mathrm{~h}$ at $37{ }^{\circ} \mathrm{C}$ and the subsequent nuclear red treatment [75]. This study represents a continuation of their previous work for identifying cancer cells in urine [98]. Moreover, Nguyen et al. fabricated a microfluidic platform for the identification of A549 human lung carcinoma cells by combining DNA aptamers and electrical impedance measurements. Similarly, self-assembled monolayers containing carboxylic groups were grown onto the surface of gold electrodes for amino-labeled aptamer conjugation. Results demonstrated a high affinity towards target cells and increased detection sensitivity at the frequency of $5 \mathrm{kHz}$ [76]. Another study performed by Anu Prathap et al. investigated the detection of circulating SK-MEL-2 human melanoma cells using an electrochemical immunosensor consisting of polyaniline nanofibers-modified electrodes with antibodies against the MC1R antigen. The sensor was able to selectively detect extremely low concentrations of 10 cells $/ 10 \mathrm{~mL}$ of solution in the presence of peripheral blood mononuclear cells [77].

Although CTCs have been preferred in the microfluidic-based sensor research for cancer diagnosis, alternative biomarkers, including microRNAs (miRNAs), circulating tumor DNA, or cancer-related proteins, can also provide important clinical information in this regard [95,99].

In this context, Lunelli et al. comparatively investigated two PDMS microdevices with spiral-shaped configurations and different surface-to-volume ratios functionalized with positive charges for attracting the negative charges phosphate groups within the miRNA backbones. Results showed that a higher surface-to-volume ratio led to an increased miRNA capture, which is of significant importance 
considering the low concentrations of miRNA biomarkers within body fluids [78]. Additionally, Kutluk et al. compared the performance of competitive and sandwich assays in terms of selectivity, sensitivity, dynamic range, reproducibility, and handling, using miRNA-197 as the target biomarker in undiluted human serum samples. Based on their results, as sensitivity and selectivity are of priority, the sandwich assay might be more advantageous [79]. Moreover, Fakhri et al. employed a colorimetric strategy using a paper microfluidic device for the detection of miRNA-21 based on the peroxidase-like activity of single-stranded DNA attached to $\mathrm{Ag} / \mathrm{Pt}$ nanoclusters. The device allowed for the quantitative measurement of miRNA, with a considerably low detection limit of $0.6 \mathrm{pM}$ [80]. However, Tian et al. achieved a detection limit of $0.0033 \mathrm{fM}$ for miRNA-21 using a lamellar $\mathrm{MnO}_{2}$ nanosheets-functionalized T-shaped duplex structure [81]. Another study investigated the efficiency of a clustered regularly interspaced short palindromic repeats (CRISPR)/Cas13a-powered microfluidic electrochemical biosensor for miRNA detection. Although the all-in-one BoC requires further improvements regarding sensitivity and reproducibility, it has proved to be an easy-to-use and efficient device with a limit of detection of $10 \mathrm{pM}$ [82].

Veselinovic et al. further demonstrated that nanostructuring the surface of electrodes leads to higher surface coverage and consequently enhanced sensor performance. Specifically, they integrated nanoporous gold multielectrode arrays within microchannels for facilitating the multiplexed detection of DNA biomarkers for cancer, namely the BRCA1, BRCA2, and p53 breast cancer-related genes, through electrophoretic guidance [83]. Similarly, Wu et al. developed an amplification-free, SERS microfluidic approach for the detection of KRAS gene, commonly known for its mutations in cancer cells [84]. Based on their initial results, a subsequent study was performed for the development of a SERS biochip to profile multiplex mutational patterns in the DNA of cancer patients [85]. Moreover, Wang et al. developed an optofluidic metasurface-based biosensor for the detection of the ErbB2 gene, a well-established breast cancer biomarker. Their biosensor involved the use of a two-dimensional periodic array of silicon nanoposts-based technique that measures the refractive index change as a result of the target molecule immobilization [86].

Other studies employed the immunosensing strategy based on the detection of carcinoma antigen (CA) 125 , as the most widely used glycoprotein for the early diagnosis of ovarian cancer $[87,88]$. On the one hand, Nami et al. developed a paper-based immunosensor by depositing silver nanoparticles onto reduced graphene oxide sheets and subsequently attaching cysteamine-functionalized gold nanoparticles that will further bond with the CA 125 antibody [87]. On the other hand, Nunna et al. developed a self-assembled monolayer by treating gold electrodes with thiourea for the subsequent attachment of the CA 125 antibody through the amine groups [88]. Similarly, Zheng et al. immobilized silver nanoparticles onto the surface of the microchannel for creating a SERS-active substrate that would allow for the attachment of antibodies to capture the target biomarkers CA 125, CA 153 simultaneously, and a carcinoembryonic antigen for breast cancer diagnosis [89]. Another study performed by Gao et al. investigated the efficiency of a SERS-based microfluidic biosensor to detect the prostate-specific antigen using magnetic beads and specific antibodies [90]. Furthermore, Guo et al. grew zinc oxide nanowires in parallel microfluidic channels for detecting the human $\alpha$-fetoprotein and carcinoembryonic antigen, achieving a limit of detection of $1 \mathrm{pg} / \mathrm{mL}$ and $100 \mathrm{fg} / \mathrm{mL}$, respectively [91].

\subsection{Microbial Infection Diagnosis}

BoC systems have also proved to be highly efficient in detecting microorganism-related infections, including bacterial, viral, and parasitic infections. In this context, a literature survey using the Scopus database and the keywords "microfluidic (bio)sensor" and "infection diagnosis" resulted in the identification of 10 papers published in 2018. All papers are summarized in Table 2 and described in the following paragraphs. 
Table 2. A summary of the identified papers investigating the use of microfluidic biosensors for microbial infection diagnosis.

\begin{tabular}{|c|c|c|c|c|c|c|c|}
\hline Microbial Type & Microbial Strain & Biosensor Type & $\begin{array}{l}\text { Measuring } \\
\text { Principle }\end{array}$ & Target & Capture Molecule & $\begin{array}{l}\text { Limit of } \\
\text { Detection }\end{array}$ & Ref \\
\hline \multirow{7}{*}{ bacteria } & Escherichia coli & $\begin{array}{l}\text { microwave-based } \\
\text { sensor }\end{array}$ & $\begin{array}{l}\text { vector network } \\
\text { analysis }\end{array}$ & Escherichia coli & - & n.r. & [100] \\
\hline & Escherichia coli & optical sensor & colorimetry & Escherichia coli & - & n.r. & [101] \\
\hline & $\begin{array}{c}\text { ampicillin-resistant } \\
\text { Escherichia coli, } \\
\text { ampicillin-susceptible } \\
\text { Escherichia coli, and } \\
\text { Bacillus subtilis }\end{array}$ & $\begin{array}{l}\text { enzyme-based } \\
\text { sensor }\end{array}$ & fluorometry & $\beta$-lactamase & - & $\begin{array}{c}1 \times 10^{4} \text { cells per } \\
\text { well }\end{array}$ & [102] \\
\hline & $\begin{array}{l}\text { Pseudomonas aeruginosa } \\
\text { and Staphylococcus aureus }\end{array}$ & immunosensor & amperometry & $\begin{array}{l}\text { Pseudomonas aeruginosa } \\
\text { and Staphylococcus aureus }\end{array}$ & $\begin{array}{c}\text { mouse anti-Pseudomonas } \\
\text { aeruginosa antibody and } \\
\text { mouse anti-Staphylococcus } \\
\text { aureus antibody }\end{array}$ & $10 \mathrm{CFU} / \mathrm{mL}$ & [103] \\
\hline & Salmonella typhimurium & $\begin{array}{l}\text { immunosensor } \\
\text { and aptasensor }\end{array}$ & amperometry & $\begin{array}{c}\text { Salmonella typhimurium } \\
\text { and } \\
\text { target DNA }\end{array}$ & $\begin{array}{c}\text { anti-Salmonella antibody } \\
\text { and } \\
\text { DNA probe }\end{array}$ & $\begin{array}{l}2.7 \times 10^{1} \mathrm{CFU} / \mathrm{mL} \\
\text { and } 0.94 \mathrm{nM}\end{array}$ & [104] \\
\hline & Salmonella typhimurium & aptasensor & $\begin{array}{c}\text { chemiresistive } \\
\text { detection }\end{array}$ & - & amine-ended aptamers & $10 \mathrm{CFU} / \mathrm{mL}$ & [105] \\
\hline & Yersinia pestis & immunosensor & $\begin{array}{c}\text { microcantilever } \\
\text { detection }\end{array}$ & Yersinia pestis & $\begin{array}{c}\text { Yersinia-specific } \\
\text { antibodies }\end{array}$ & n.r. & [106] \\
\hline \multirow[b]{2}{*}{ viruses } & human adenovirus & aptasensor & fluorimetry & extracted viral DNA & DNA probe & 10 virus copies & [107] \\
\hline & hepatitis B virus & aptasensor & $\begin{array}{c}\text { differential pulse } \\
\text { voltammetry }\end{array}$ & target DNA & DNA probe & $1.45 \mathrm{pM}$ & [108] \\
\hline parasites & Plasmodium falciparum & immunosensor & magnetometry & $\begin{array}{c}\text { Plasmodium falciparum } \\
\text { lactate } \\
\text { dehydrogenase }\end{array}$ & $\begin{array}{l}\text { Anti- Plasmodium lactate } \\
\text { dehydrogenase } \\
\text { monoclonal capture and } \\
\text { c-MAb and bd-MAb } \\
\text { detection antibodies }\end{array}$ & $200 \mathrm{ng} / \mathrm{mL}$ & [109] \\
\hline
\end{tabular}


First, the identified papers investigated the detection efficiency of microfluidic biosensors towards Escherichia coli, Bacillus subtilis, Pseudomonas aeruginosa, Staphylococcus aureus, Salmonella typhimurium, and Yersinia pestis bacterial strains. Specifically, Narang et al. reported developing a microfluidic chip resting onto a resonator that emits an electrical signal further analyzed through a vector network analyzer. This device allowed for the real-time detection of Escherichia coli concentration and proliferation [100]. Furthermore, He et al. fabricated a paper-based microfluidic device for detecting Escherichia coli bacteria and subsequently its susceptibility towards a variety of antibiotics, including amoxicillin, ciprofloxacin, gentamicin, and nitrofurantoin, through observable color changes. Results indicated the potential of the device for diagnosing bacterial infections and providing the means for accurate antibiotic prescribing [101]. Additionally, Li et al. developed a droplet-based microfluidic platform containing a fluorescence-producing $\beta$-lactamase sensor (Fluorocillin sensor) for the detection and quantification of antibiotic-resistant bacteria [102]. By contrast, Lee et al. proposed a microfluidic platform employing redox-active gold nanoparticles conjugated with active electrochemical molecules and specific antibodies for subsequent attachment onto the bacteria surface. Their results showed a limit of detection of $10 \mathrm{CFU} / \mathrm{mL}$ and a dynamic range of $10-105 \mathrm{CFU} / \mathrm{mL}$, thus holding great potential in bacteremia diagnosis [103]. Furthermore, two nanotechnology-enhanced strategies for the detection of Salmonella typhimurium were reported in the literature. On the one hand, Savas et al. reported the use of antibody- and DNA-based biosensors integrated within a fully-automated custom-designed microfluidic device employing gold nanoparticles for increasing sensitivity [104].

On the other hand, Thiha et al. reported the application of amine-ended aptamers immobilized onto suspended carbon nanowire surface integrated within a microfluidic chip [105]. Finally, Liu et al. investigated the efficiency of a microcantilever biosensor for the detection of Yersinia pestis using a microfluidic platform. In their study, the surface of the microcantilevers was functionalized for the subsequent attachment of two types of Yersinia-specific antibodies [106].

Second, the identified papers investigated the detection efficiency of microfluidic biosensors towards human adenovirus, and hepatitis B virus. On one hand, Jin et al. fabricated a novel microfluidic approach for both the isolation of viral DNA and its subsequent detection using an optical biosensor. In this manner, as sample quality is critical in infectious disease diagnosis, this method ensures a standardized and accurate sample preparation, resulting in a high quality and quantity of the viral DNA extracted [107]. On the other hand, Srisomwat et al. reported the development of a pop-up label-free electrochemical paper-based microfluidic device designed for DNA sensing from extracted DNA samples [108].

Ruiz-Vega et al. reported the development of an electrochemical device for the fast quantitative diagnosis of malaria. Using magnetic beads, their strategy allows for a single-step magneto-immunosensing through a single-use microfluidic paper double-sided screen-printed carbon electrode [109].

\subsection{Neurodegenerative Disorder Diagnosis}

Recent years have witnessed an increasing number of studies regarding the identification of neurodegeneration-related biomarkers [110-112]. In this regard, various biomarkers including amyloid- $\beta$ peptides, tau proteins, neurofilament light, for neuronal injury, neurogranin, BACE1, SNAP-25, and synaptotagmin for synaptic dysfunction and/or loss, sTREM2, YKL-40, interleukins, tumor necrosis factor $\alpha$, and lactoferrin for neuroinflammation due to the activation of microglia and astrocytes, and clusterin for apoptosis [113-132]. There are many studies investigating the efficiency of biosensors for the identification of these biomarkers [133,134]. However, the integration of microfluidics within these biosensors could bring the advantages of low sample and reagent consumption, high sensitivity and specificity, and low detection limit. However, the application of microfluidic biosensors for early diagnosis is still limited.

The literature survey using the Scopus database and the keywords "microfluidic (bio)sensor" and "neurodegenerative disorder diagnosis", "neurodegeneration diagnosis", "Alzheimer diagnosis", 
"Parkinson diagnosis", or "Huntington diagnosis" resulted in the identification of only one paper published since 2018.

Specifically, Ricci et al. developed a label-free biosensor using electrolyte-gated organic field-effect transistors for the electronic transduction for the identification of $\alpha$-synuclein, a small protein known to be implicated in a series of neurodegenerative disorders, including Parkinson's disease, Alzheimer's disease, dementia with Lewy bodies, and multiple system atrophy [135-138]. The monoclonal anti- $\alpha$-synuclein antibody was grafted on the gate electrode via two methods, namely Protein G and self-assembled monolayers. The integration of the biosensor within the microfluidic device has provided a sensitivity of up to $37( \pm 5) \mathrm{mV} / \mathrm{dec}$ and a limit-of-detection of $0.25 \mathrm{pM}$ [139].

Moreover, Song et al. developed a label-free nanosensor incorporating a nanopore layer consisting of an anodic aluminum oxide embedded in a nanostructured Fabry-Perot interference cavity, which serves as the sensing element for the detection of amyloid- $\beta 42$ and total-tau biomarkers. Specifically, the white light reflected from the nanosensor forms interference fringes that are further utilized as transducing signals. The efficiency and specificity of detection have proved to be up to $7.8 \mathrm{pg} / \mathrm{mL}$ of $\mathrm{A} \beta 42$ and $15.6 \mathrm{pg} / \mathrm{mL}$ of T-au in buffer [140]. Furthermore, Liu et al. fabricated a nanosensor for the highly sensitive and selective monitorization of extracellular potassium levels within the brain, a potential indicator for neurological disorders, including Alzheimer's disease or epilepsy [141,142]. The optical readout is achieved by incorporating commercially available $\mathrm{K}^{+}$indicators into mesoporous silica nanoparticles [142].

Although the number of studies is considerably limited, there is a great potential of microfluidic biosensors for the early and accurate diagnosis of neurodegenerative disorders, thus avoiding a great burden on the health systems $[133,143]$.

\section{Conclusions and Future Perspectives}

BoC systems are based on micro-total analysis systems, which aim to provide complete analytical microscaled systems, thus allowing for the performance of standard laboratory functions, including sample injection, mixing, reaction, separation, and enrichment, and analyte detection. Specifically, these systems integrate biosensors with microfluidic technologies, resulting in higher detection sensitivity and specificity, resolution, automation, throughput, reproducibility, reliability, and accuracy. Therefore, the emergence of $\mathrm{BoC}$ systems has led to substantial advancements in PoC diagnostic applications that could bring significant improvements, especially in the resource-limited environment of the developing countries. It has brought diagnostics out of central laboratories to the patient bedside. While there are many breakthrough studies regarding microfluidic biosensors' application for cancer and infectious disease diagnosis, neurodegenerative disorder diagnostics has not yet benefitted from these technologies. Since recent years have witnessed tremendous advancements in the neurodegenerative biomarker arena, future perspectives should focus on the development of BoC systems for diagnosing such disorders.

Author Contributions: C.C., A.C.B., A.M.G. and E.A. designed and wrote the paper. All authors have read and agreed to the published version of the manuscript.

Funding: This work was supported by a grant from the Romanian National Authority for Scientific Research and Innovation, UEFISCDI, project number TE 103, Code: PN-III-P1-1.1-TE-2019-1450, entitled Multifunctional lab-on-a-chip microfluidic platform for the fabrication of nanoparticles.

Acknowledgments: This work was supported by a grant from the Romanian National Authority for Scientific Research and Innovation, UEFISCDI, project number TE 103, Code: PN-III-P1-1.1-TE-2019-1450, entitled Multifunctional lab-on-a-chip microfluidic platform for the fabrication of nanoparticles.

Conflicts of Interest: The authors declare no conflict of interest. 


\section{References}

1. Khan, N.I.; Song, E. Lab-on-a-Chip Systems for Aptamer-Based Biosensing. Micromachines 2020, 11, 220. [CrossRef] [PubMed]

2. Husain, Q. Carbon nanotubes mediated immobilized glucose oxidase biosensors as an effective and sensitive analytical tool. Biointerface Res. Appl. Chem. 2018, 8, 3060-3074.

3. Wegmann, M.; Scharr, M. Chapter 8-Synthesis of Magnetic Iron Oxide Nanoparticles. In Precision Medicine; Deigner, H.-P., Kohl, M., Eds.; Academic Press: Cambridge, MA, USA, 2018; pp. 145-181. [CrossRef]

4. Kumar, N.; Upadhyay, L.S.B. 19-Polymeric gels for biosensing applications. In Polymeric Gels; Pal, K., Banerjee, I., Eds.; Woodhead Publishing: Cambridge, UK, 2018; pp. 487-503. [CrossRef]

5. Muguruma, H. Biosensors: Enzyme Immobilization Chemistry. In Encyclopedia of Interfacial Chemistry; Wandelt, K., Ed.; Elsevier: Oxford, UK, 2018; pp. 64-71. [CrossRef]

6. Manikandan, R.; Charumathe, N.; Fariha Begum, A. Application of Biosensor. Bull. Sci. Res. 2019, 1, 34-40. [CrossRef]

7. Dai, Y.; Furst, A.; Liu, C.C. Strand displacement strategies for biosensor applications. Trends Biotechnol. 2019, 37, 1367-1382. [CrossRef]

8. Mohamad, A.; Rizwan, M.; Keasberry, N.A.; Ahmed, M.U. Fabrication of label-free electrochemical food biosensor for the sensitive detection of ovalbumin on nanocomposite-modified graphene electrode. Biointerface Res. Appl. Chem. 2019, 9, 4655-4662. [CrossRef]

9. Bhalla, N.; Jolly, P.; Formisano, N.; Estrela, P. Introduction to biosensors. Essays Biochem. 2016, 60, 1-8. [CrossRef]

10. Niri, A.D.; Faridi-Majidi, R.; Saber, R.; Khosravani, M.; Adabi, M. Electrospun carbon nanofiber-based electrochemical biosensor for the detection of hepatitis B virus. Biointerface Res. Appl. Chem. 2019, 9, 4022-4026. [CrossRef]

11. Parkhey, P.; Mohan, S.V. Chapter 6.1-Biosensing Applications of Microbial Fuel Cell: Approach Toward Miniaturization. In Microbial Electrochemical Technology; Mohan, S.V., Varjani, S., Pandey, A., Eds.; Elsevier: Amsterdam, The Netherlands, 2019; pp. 977-997. [CrossRef]

12. Malinee, M.; Kumar, A.; Dhiman, A.; Sharma, T.K. Chapter 8-Aptamer-Mediated Nanobiosensing for Health Monitoring. In Advanced Biosensors for Health Care Applications; Inamuddin, K.R., Mohammad, A., Asiri, A.M., Eds.; Elsevier: Amsterdam, The Netherlands, 2019; pp. 227-248. [CrossRef]

13. Sadana, A.; Sadana, N.; Sadana, R. 3-Different Instrumentation Techniques. In A Fractal Analysis of Chemical Kinetics with Applications to Biological and Biosensor Interfaces; Sadana, A., Sadana, N., Sadana, R., Eds.; Elsevier: Amsterdam, The Netherlands, 2018; pp. 43-67. [CrossRef]

14. Carpenter, A.C.; Paulsen, I.T.; Williams, T.C. Blueprints for Biosensors: Design, Limitations, and Applications. Genes 2018, 9, 375. [CrossRef]

15. Rajpoot, K. Recent Advances and Applications of Biosensors in Novel Technology. Biosens. J. 2017, 6, 1-12.

16. Kim, J.; Campbell, A.S.; de Ávila, B.E.-F.; Wang, J. Wearable biosensors for healthcare monitoring. Nat. Biotechnol. 2019, 37, 389-406. [CrossRef]

17. Sevenler, D.; Trueb, J.; Ünlü, M.S. Beating the reaction limits of biosensor sensitivity with dynamic tracking of single binding events. Proc. Natl. Acad. Sci. USA 2019, 116, 4129-4134. [CrossRef] [PubMed]

18. Kumar, S.; Park, H.; Cho, H.; Siddique, R.H.; Narasimhan, V.; Yang, D.; Choo, H. Overcoming evanescent field decay using 3D-tapered nanocavities for on-chip targeted molecular analysis. Nat. Commun. 2020, 11, 2930. [CrossRef] [PubMed]

19. Spitzberg, J.D.; Zrehen, A.; van Kooten, X.F.; Meller, A. Plasmonic-Nanopore Biosensors for Superior Single-Molecule Detection. Adv. Mater. 2019, 31, 1900422. [CrossRef] [PubMed]

20. Gaudin, V. Chapter 11-Receptor-based electrochemical biosensors for the detection of contaminants in food products. In Electrochemical Biosensors; Ensafi, A.A., Ed.; Elsevier: Amsterdam, The Netherlands, 2019; pp. 307-365. [CrossRef]

21. Francis, M.P.; Kemper, N.; Maghdouri-White, Y.; Thayer, N. 9-Additive manufacturing for biofabricated medical device applications. In Additive Manufacturing; Zhang, J., Jung, Y.-G., Eds.; Butterworth-Heinemann: Oxford, UK, 2018; pp. 311-344. [CrossRef]

22. Wibowo, D.; Zhao, C.-X.; He, Y. Chapter 2-Fluid properties and hydrodynamics of microfluidic systems. In Microfluidics for Pharmaceutical Applications; Santos, H.A., Liu, D., Zhang, H., Eds.; William Andrew Publishing: Norwich, NY, USA, 2019; pp. 37-77. [CrossRef] 
23. Bohr, A.; Colombo, S.; Jensen, H. Chapter 15-Future of microfluidics in research and in the market. In Microfluidics for Pharmaceutical Applications; Santos, H.A., Liu, D., Zhang, H., Eds.; William Andrew Publishing: Norwich, NY, USA, 2019; pp. 425-465. [CrossRef]

24. Nainys, J.; Milkus, V.; Mažutis, L. Chapter 13-Single-cell screening using microfluidic systems. In Microfluidics for Pharmaceutical Applications; Santos, H.A., Liu, D., Zhang, H., Eds.; William Andrew Publishing: Norwich, NY, USA, 2019; pp. 353-367. [CrossRef]

25. Luka, G.; Ahmadi, A.; Najjaran, H.; Alocilja, E.; DeRosa, M.; Wolthers, K.; Malki, A.; Aziz, H.; Althani, A.; Hoorfar, M. Microfluidics Integrated Biosensors: A Leading Technology towards Lab-on-a-Chip and Sensing Applications. Sensors 2015, 15, 30011-30031. [CrossRef] [PubMed]

26. Anik, Ü. 12-Electrochemical medical biosensors for POC applications. In Medical Biosensors for Point of Care (POC) Applications; Narayan, R.J., Ed.; Woodhead Publishing: Cambridge, UK, 2017; pp. 275-292. [CrossRef]

27. Khalid, N.; Arif, S.; Kobayashi, I.; Nakajima, M. Chapter 14-Lab-on-a-chip techniques for high-throughput proteomics and drug discovery. In Microfluidics for Pharmaceutical Applications; Santos, H.A., Liu, D., Zhang, H., Eds.; William Andrew Publishing: Norwich, NY, USA, 2019; pp. 371-422. [CrossRef]

28. Mukherji, S.; Mondal, D. 5-Lab-on-chip (LOC) devices for point of care (POC) applications. In Medical Biosensors for Point of Care (POC) Applications; Narayan, R.J., Ed.; Woodhead Publishing: Cambridge, UK, 2017; pp. 99-131. [CrossRef]

29. Malhotra, B.D.; Ali, M.A. Chapter 9-Microfluidic Biosensor. In Nanomaterials for Biosensors; Malhotra, B.D., Ali, M.A., Eds.; William Andrew Publishing: Norwich, NY, USA, 2018; pp. 263-293. [CrossRef]

30. Loo, J.F.; Ho, A.H.; Turner, A.P.F.; Mak, W.C. Integrated Printed Microfluidic Biosensors. Trends Biotechnol. 2019, 37, 1104-1120. [CrossRef]

31. Liao, Z.; Wang, J.; Zhang, P.; Zhang, Y.; Miao, Y.; Gao, S.; Deng, Y.; Geng, L. Recent advances in microfluidic chip integrated electronic biosensors for multiplexed detection. Biosens. Bioelectron. 2018, 121, 272-280. [CrossRef]

32. Liao, Z.; Zhang, Y.; Li, Y.; Miao, Y.; Gao, S.; Lin, F.; Deng, Y.; Geng, L. Microfluidic chip coupled with optical biosensors for simultaneous detection of multiple analytes: A review. Biosens. Bioelectron. 2019, 126, 697-706. [CrossRef]

33. Castaño-Álvarez, M.; Pozo-Ayuso, D.F.; Fernández-la-Villa, A. Integrated microfluidic electrochemical sensors to enhance automated flow analysis systems. In Laboratory Methods in Dynamic Electroanalysis; Elsevier: Amsterdam, The Netherlands, 2020; pp. 161-170.

34. Choi, J.R. Development of Point-of-Care Biosensors for COVID-19. Front. Chem. 2020, 8, 517. [CrossRef]

35. Manocha, A.; Bhargava, S. Emerging challenges in point-of-care testing. Curr. Med. Res. Pract. 2019, 9, 227-230. [CrossRef]

36. Liu, D.; Wang, J.; Wu, L.; Huang, Y.; Zhang, Y.; Zhu, M.; Wang, Y.; Zhu, Z.; Yang, C. Trends in miniaturized biosensors for point-of-care testing. TrAC Trends Anal. Chem. 2020, 122, 115701. [CrossRef]

37. Hochstetter, A. Lab-on-a-Chip Technologies for the Single Cell Level: Separation, Analysis, and Diagnostics. Micromachines 2020, 11, 468. [CrossRef]

38. Jin, J.; Nguyen, N.-T. Manipulation schemes and applications of liquid marbles for micro total analysis systems. Microelectron. Eng. 2018, 197, 87-95. [CrossRef]

39. Atalay, Y.T.; Vermeir, S.; Witters, D.; Vergauwe, N.; Verbruggen, B.; Verboven, P.; Nicolaï, B.M.; Lammertyn, J. Microfluidic analytical systems for food analysis. Trends Food Sci. Technol. 2011, 22, 386-404. [CrossRef]

40. Cai, G.; Xue, L.; Zhang, H.; Lin, J.J.M. A review on micromixers. Micromachines 2017, 8, 274. [CrossRef] [PubMed]

41. Nikoleli, G.-P.; Siontorou, C.G.; Nikolelis, D.P.; Bratakou, S.; Karapetis, S.; Tzamtzis, N. Chapter 13-Biosensors Based on Microfluidic Devices Lab-on-a-Chip and Microfluidic Technology. In Nanotechnology and Biosensors; Nikolelis, D.P., Nikoleli, G.-P., Eds.; Elsevier: Amsterdam, The Netherlands, 2018; pp. 375-394. [CrossRef]

42. Keçili, R.; Büyüktiryaki, S.; Hussain, C.M. 8-Micro total analysis systems with nanomaterials. In Handbook of Nanomaterials in Analytical Chemistry; Mustansar, H.C., Ed.; Elsevier: Amsterdam, The Netherlands, 2020; pp. 185-198. [CrossRef]

43. Qian, J.-Y.; Hou, C.-W.; Li, X.-J.; Jin, Z.-J.J.M. Actuation Mechanism of Microvalves: A Review. Micromachines 2020, 11, 172. [CrossRef] [PubMed] 
44. Sun, Y.-S. Comparison of Chip Inlet Geometry in Microfluidic Devices for Cell Studies. Molecules 2016, 21, 778. [CrossRef] [PubMed]

45. Whulanza, Y.; Hakim, A.T.; Utomo, S.M.; Irwansyah, R.; Charmet, J.J.E. Design and Characterization of Finger-Controlled Micropump for Lab-on-a-Chip Devices. Evergreen 2019, 6, 108-113. [CrossRef]

46. Guevara-Pantoja, P.E.; Jiménez-Valdés, R.J.; García-Cordero, J.L.; Caballero-Robledo, G.A. Pressure-actuated monolithic acrylic microfluidic valves and pumps. Lab Chip 2018, 18, 662-669. [CrossRef]

47. Agrawal, P.; Gandhi, P.S.; Majumder, M.; Kumar, P. Insight into the Design and Fabrication of a Leaf-Mimicking Micropump. Phys. Rev. App. 2019, 12, 031002. [CrossRef]

48. Eluru, G.; Adhikari, J.V.; Chanda, P.; Gorthi, S.S. Hand-Powered Elastomeric Pump for Microfluidic Point-of-Care Diagnostics. Micromachines 2020, 11, 67. [CrossRef]

49. Avvari, R.K. A novel two-indenter based micro-pump for lab-on-a-chip application: Modeling and characterizing flows for a non-Newtonian fluid. bioRxiv 2020. [CrossRef]

50. Ferraro, D.; Serra, M.; Ferrante, I.; Viovy, J.L.; Descroix, S. Microfluidic valve with zero dead volume and negligible back-flow for droplets handling. Sens. Actuators B Chem. 2018, 258, 1051-1059. [CrossRef]

51. Zhang, X.; Oseyemi, A.E.J.M. Microfluidic Passive Valve with Ultra-Low Threshold Pressure for High-Throughput Liquid Delivery. Chem. Eng. Process. Process. Intensif. 2019, 10, 798. [CrossRef] [PubMed]

52. Bayareh, M.; Ashani, M.N.; Usefian, A. Active and passive micromixers: A comprehensive review. Chem. Eng. Process. Process. Intensif. 2020, 147, 107771. [CrossRef]

53. Raza, W.; Hossain, S.; Kim, K.-Y. A Review of Passive Micromixers with a Comparative Analysis. Micromachines 2020, 11, 455. [CrossRef] [PubMed]

54. Lee, C.-Y.; Fu, L.-M. Recent advances and applications of micromixers. Sens. Actuators B Chem. 2018, 259, 677-702. [CrossRef]

55. Liu, X.; Lin, B. Materials Used in Microfluidic Devices. In Encyclopedia of Microfluidics and Nanofluidics; Li, D., Ed.; Springer: Boston, MA, USA, 2008; pp. 1065-1068. [CrossRef]

56. Hosseini, M.-S.; Amjadi, I.; Mozafari, M. Chapter 18-State-of-the-art and future perspectives of functional polymers. In Advanced Functional Polymers for Biomedical Applications; Mozafari, M., Singh Chauhan, N.P., Eds.; Elsevier: Amsterdam, The Netherlands, 2019; pp. 383-395. [CrossRef]

57. Gao, B.; Li, X.; Yang, Y.; Chu, J.; He, B. Emerging paper microfluidic devices. Analyst 2019, 144, 6497-6511. [CrossRef]

58. Böhm, A.; Biesalski, M. Paper-based microfluidic devices: A complex low-cost material in high-tech applications. MRS Bull. 2017, 42, 356-364. [CrossRef]

59. Soum, V.; Park, S.; Brilian, A.I.; Kwon, O.-S.; Shin, K.J.M. Programmable paper-based microfluidic devices for biomarker detections. Micromachines 2019, 10, 516. [CrossRef]

60. Strong, E.B.; Schultz, S.A.; Martinez, A.W.; Martinez, N.W. Fabrication of Miniaturized Paper-Based Microfluidic Devices (MicroPADs). Sci. Rep. 2019, 9, 7. [CrossRef]

61. Campuzano, S.; Yáñez-Sedeño, P.; Pingarrón, J.M. Current trends and challenges in bioelectrochemistry for non-invasive and early diagnosis. Curr. Opin. Electrochem. 2018, 12, 81-91. [CrossRef]

62. Cheng, S.-J.; Hsieh, K.Y.; Chen, S.-L.; Chen, C.-Y.; Huang, C.-Y.; Tsou, H.-I.; Kumar, P.V.; Hsieh, J.C.-H.; Chen, G.-Y. Microfluidics and Nanomaterial-based Technologies for Circulating Tumor Cell Isolation and Detection. Sensors 2020, 20, 1875. [CrossRef] [PubMed]

63. Sierra, T.; Crevillen, A.G.; Escarpa, A. Electrochemical detection based on nanomaterials in CE and microfluidic systems. Electrophoresis 2019, 40, 113-123. [CrossRef] [PubMed]

64. Sun, D.; Chen, Z.; Wu, M.; Zhang, Y. Nanomaterial-based Microfluidic Chips for the Capture and Detection of Circulating Tumor Cells. Nanotheranostics 2017, 1, 389-402. [CrossRef] [PubMed]

65. Testa, G.; Persichetti, G.; Bernini, R. Optofluidic Approaches for Enhanced Microsensor Performances. Sensors 2015, 15, 465-484. [CrossRef] [PubMed]

66. Xu, Z.; Lu, M.; Jin, H.; Chen, T.; Bond, T.C. Nanomaterials for Optical Sensing and Sensors: Plasmonics, Raman, and Optofluidics. J. Nanomater. 2015, 2015, 162537. [CrossRef]

67. Liu, S.; Hawkins, A.R.; Schmidt, H. Optofluidic devices with integrated solid-state nanopores. Mikrochim. Acta 2016, 183, 1275-1287. [CrossRef]

68. Farmani, A.; Soroosh, M.; Mozaffari, M.; Daghoghi, T. Optical nanosensors for cancer and virus detections. Nanosens. Smart Cities 2020. [CrossRef] 
69. Rickard, J.J.S.; Di-Pietro, V.; Smith, D.J.; Davies, D.J.; Belli, A.; Oppenheimer, P.G. Rapid optofluidic detection of biomarkers for traumatic brain injury via surface-enhanced Raman spectroscopy. Nat. Biomed. Eng. 2020, 4, 610-623. [CrossRef]

70. Garcia-Cordero, J.L.; Maerkl, S.J. Microfluidic systems for cancer diagnostics. Curr. Opin. Biotechnol. 2020, 65, 37-44. [CrossRef]

71. Silva, A.C.Q.; Vilela, C.; Santos, H.A.; Silvestre, A.J.D.; Freire, C.S.R. Recent trends on the development of systems for cancer diagnosis and treatment by microfluidic technology. App. Mater. Today 2020, 18, 100450. [CrossRef]

72. Kulasinghe, A.; Wu, H.; Punyadeera, C.; Warkiani, M.E. The Use of Microfluidic Technology for Cancer Applications and Liquid Biopsy. Micromachines 2018, 9, 397. [CrossRef] [PubMed]

73. Tavakoli, H.; Zhou, W.; Ma, L.; Perez, S.; Ibarra, A.; Xu, F.; Zhan, S.; Li, X. Recent advances in microfluidic platforms for single-cell analysis in cancer biology, diagnosis and therapy. TrAC Trends Anal. Chem. 2019, 117, 13-26. [CrossRef] [PubMed]

74. Cetin, D.; Okan, M.; Bat, E.; Kulah, H. A comparative study on EpCAM antibody immobilization on gold surfaces and microfluidic channels for the detection of circulating tumor cells. Colloids Surf. B Biointerfaces 2020, 188. [CrossRef]

75. Chan, K.M.; Vasilev, K.; Shirazi, H.S.; McNicholas, K.; Li, J.; Gleadle, J.; MacGregor, M. Biosensor device for the photo-specific detection of immuno-captured bladder cancer cells using hexaminolevulinate: An ex-vivo study. Photodiagn. Photodyn. Ther. 2019, 28, 238-247. [CrossRef]

76. Nguyen, N.V.; Yang, C.H.; Liu, C.J.; Kuo, C.H.; Wu, D.C.; Jen, C.P. An aptamer-based capacitive sensing platform for specific detection of lung carcinoma cells in the microfluidic chip. Biosensors 2018, 8, 98. [CrossRef]

77. Anu Prathap, M.U.; Castro-Pérez, E.; Jiménez-Torres, J.A.; Setaluri, V.; Gunasekaran, S. A flow-through microfluidic system for the detection of circulating melanoma cells. Biosens. Bioelectron. 2019, 142. [CrossRef]

78. Lunelli, L.; Barbaresco, F.; Scordo, G.; Potrich, C.; Vanzetti, L.; Marasso, S.L.; Cocuzza, M.; Pirri, C.F.; Pederzolli, C. PDMS-based microdevices for the capture of MicroRNA biomarkers. Appl. Sci. 2020, 10, 3867. [CrossRef]

79. Kutluk, H.; Bruch, R.; Urban, G.A.; Dincer, C. Impact of assay format on miRNA sensing: Electrochemical microfluidic biosensor for miRNA-197 detection. Biosens. Bioelectron. 2020, 148. [CrossRef]

80. Fakhri, N.; Abarghoei, S.; Dadmehr, M.; Hosseini, M.; Sabahi, H.; Ganjali, M.R. Paper based colorimetric detection of miRNA-21 using Ag/Pt nanoclusters. Spectrochim. Acta Part A Mol. Biomol. Spectrosc. 2020, 227. [CrossRef]

81. Tian, T.; Li, L.; Zhang, Y.; Liu, H.; Zhang, L.; Yan, M.; Yu, J. Dual-mode fluorescence biosensor platform based on T-shaped duplex structure for detection of microRNA and folate receptor. Sensors Actuators B Chem. 2018, 261,44-50. [CrossRef]

82. Bruch, R.; Baaske, J.; Chatelle, C.; Meirich, M.; Madlener, S.; Weber, W.; Dincer, C.; Urban, G.A. CRISPR/Cas13a-Powered Electrochemical Microfluidic Biosensor for Nucleic Acid Amplification-Free miRNA Diagnostics. Adv. Mater. 2019, 31. [CrossRef] [PubMed]

83. Veselinovic, J.; Li, Z.; Daggumati, P.; Seker, E. Electrically guided DNA immobilization and multiplexed DNA detection with nanoporous gold electrodes. Nanomaterials 2018, 8, 351. [CrossRef] [PubMed]

84. Wu, L.; Garrido-Maestu, A.; Guerreiro, J.R.L.; Carvalho, S.; Abalde-Cela, S.; Prado, M.; Diéguez, L. Amplification-free SERS analysis of DNA mutation in cancer cells with single-base sensitivity. Nanoscale 2019, 11, 7781-7789. [CrossRef]

85. Wu, L.; Teixeira, A.; Garrido-Maestu, A.; Muinelo-Romay, L.; Lima, L.; Santos, L.L.; Prado, M.; Diéguez, L. Profiling DNA mutation patterns by SERS fingerprinting for supervised cancer classification. Biosens. Bioelectron. 2020, 165. [CrossRef]

86. Wang, Y.; Ali, M.A.; Chow, E.K.C.; Dong, L.; Lu, M. An optofluidic metasurface for lateral flow-through detection of breast cancer biomarker. Biosens. Bioelectron. 2018, 107, 224-229. [CrossRef]

87. Bahavarnia, F.; Saadati, A.; Hassanpour, S.; Hasanzadeh, M.; Shadjou, N.; Hassanzadeh, A. Paper based immunosensing of ovarian cancer tumor protein CA 125 using novel nano-ink: A new platform for efficient diagnosis of cancer and biomedical analysis using microfluidic paper-based analytical devices ( $\mu$ PAD). Int. J. Biol. Macromol. 2019, 138, 744-754. [CrossRef] 
88. Nunna, B.B.; Mandal, D.; Lee, J.U.; Zhuang, S.; Lee, E.S. Sensitivity Study of Cancer Antigens (CA-125) Detection Using Interdigitated Electrodes Under Microfluidic Flow Condition. BioNanoScience 2019, 9, $203-214$. [CrossRef]

89. Zheng, Z.; Wu, L.; Li, L.; Zong, S.; Wang, Z.; Cui, Y. Simultaneous and highly sensitive detection of multiple breast cancer biomarkers in real samples using a SERS microfluidic chip. Talanta 2018, 188, 507-515. [CrossRef]

90. Gao, R.; Lv, Z.; Mao, Y.; Yu, L.; Bi, X.; Xu, S.; Cui, J.; Wu, Y. SERS-Based Pump-Free Microfluidic Chip for Highly Sensitive Immunoassay of Prostate-Specific Antigen Biomarkers. ACS Sens. 2019, 4, 938-943. [CrossRef]

91. Guo, L.; Shi, Y.; Liu, X.; Han, Z.; Zhao, Z.; Chen, Y.; Xie, W.; Li, X. Enhanced fluorescence detection of proteins using $\mathrm{ZnO}$ nanowires integrated inside microfluidic chips. Biosens. Bioelectron. 2018, 99, 368-374. [CrossRef] [PubMed]

92. Sierra, J.; Marrugo-Ramírez, J.; Rodriguez-Trujillo, R.; Mir, M.; Samitier, J. Sensor-Integrated Microfluidic Approaches for Liquid Biopsies Applications in Early Detection of Cancer. Sensors 2020, 20, 1317. [CrossRef] [PubMed]

93. Nasiri, R.; Shamloo, A.; Ahadian, S.; Amirifar, L.; Akbari, J.; Goudie, M.J.; Lee, K.; Ashammakhi, N.; Dokmeci, M.R.; Di Carlo, D.; et al. Microfluidic-Based Approaches in Targeted Cell/Particle Separation Based on Physical Properties: Fundamentals and Applications. Small 2020, 16, 2000171. [CrossRef] [PubMed]

94. Xu, X.; Jiang, Z.; Wang, J.; Ren, Y.; Wu, A. Microfluidic applications on circulating tumor cell isolation and biomimicking of cancer metastasis. Electrophoresis 2020, 41, 933-951. [CrossRef]

95. Davaran, S.; Sadeghinia, M.; Jamalpoor, Z.; Raeisdasteh Hokmabad, V.; Doosti-Telgerd, M.; Karimian, A.; Sadeghinia, Z.; Khalilifard, J.; keramt, A.; Moradikhah, F.; et al. Multiple functions of microfluidic platforms: Characterization and applications in tissue engineering and diagnosis of cancer. Electrophoresis 2020, 41, 1081-1094. [CrossRef]

96. Liang, W.; Yang, X.; Wang, J.; Wang, Y.; Yang, W.; Liu, L. Determination of Dielectric Properties of Cells using AC Electrokinetic-based Microfluidic Platform: A Review of Recent Advances. Micromachines 2020, 11, 513. [CrossRef]

97. Liang, W.; Liu, J.; Yang, X.; Zhang, Q.; Yang, W.; Zhang, H.; Liu, L. Microfluidic-based cancer cell separation using active and passive mechanisms. Microfluid. Nanofluid. 2020, 24. [CrossRef]

98. Macgregor-Ramiasa, M.; McNicholas, K.; Ostrikov, K.; Li, J.; Michael, M.; Gleadle, J.M.; Vasilev, K. A platform for selective immuno-capture of cancer cells from urine. Biosens. Bioelectron. 2017, 96, 373-380. [CrossRef]

99. Iliescu, F.S.; Poenar, D.P.; Yu, F.; Ni, M.; Chan, K.H.; Cima, I.; Taylor, H.K.; Cima, I.; Iliescu, C. Recent advances in microfluidic methods in cancer liquid biopsy. Biomicrofluidics 2019, 13. [CrossRef]

100. Narang, R.; Mohammadi, S.; Ashani, M.M.; Sadabadi, H.; Hejazi, H.; Zarifi, M.H.; Sanati-Nezhad, A. Sensitive, Real-time and Non-Intrusive Detection of Concentration and Growth of Pathogenic Bacteria using Microfluidic-Microwave Ring Resonator Biosensor. Sci. Rep. 2018, 8, s41598. [CrossRef]

101. He, P.J.W.; Katis, I.N.; Kumar, A.J.U.; Bryant, C.A.; Keevil, C.W.; Somani, B.K.; Mahobia, N.; Eason, R.W.; Sones, C.L. Laser-patterned paper-based sensors for rapid point-of-care detection and antibiotic-resistance testing of bacterial infections. Biosens. Bioelectron. 2020, 152. [CrossRef] [PubMed]

102. Li, Y.; Cherukury, H.; Labanieh, L.; Zhao, W.; Kang, D.K. Rapid detection of $\beta$-lactamase-producing bacteria using the integrated comprehensive droplet digital detection (Ic 3d) system. Sensors 2020, 20, 4667. [CrossRef] [PubMed]

103. Lee, C.W.; Chang, H.Y.; Wu, J.K.; Tseng, F.G. Ultra-sensitive electrochemical detection of bacteremia enabled by redox-active gold nanoparticles (raGNPs) in a nano-sieving microfluidic system (NS-MFS). Biosens. Bioelectron. 2019, 133, 215-222. [CrossRef] [PubMed]

104. Savas, S.; Ersoy, A.; Gulmez, Y.; Kilic, S.; Levent, B.; Altintas, Z. Nanoparticle enhanced antibody and DNA biosensors for sensitive detection of Salmonella. Materials 2018, 11, 1541. [CrossRef] [PubMed]

105. Thiha, A.; Ibrahim, F.; Muniandy, S.; Dinshaw, I.J.; Teh, S.J.; Thong, K.L.; Leo, B.F.; Madou, M. All-carbon suspended nanowire sensors as a rapid highly-sensitive label-free chemiresistive biosensing platform. Biosens. Bioelectron. 2018, 107, 145-152. [CrossRef] [PubMed]

106. Liu, X.; Wang, L.; Zhao, J.; Zhu, Y.; Yang, J.; Yang, F. Enhanced binding efficiency of microcantilever biosensor for the detection of yersinia. Sensors 2019, 19, 3326. [CrossRef] 
107. Jin, C.E.; Lee, T.Y.; Koo, B.; Sung, H.; Kim, S.H.; Shin, Y. Rapid virus diagnostic system using bio-optical sensor and microfluidic sample processing. Sens. Actuators B Chem. 2018, 255, 2399-2406. [CrossRef]

108. Srisomwat, C.; Teengam, P.; Chuaypen, N.; Tangkijvanich, P.; Vilaivan, T.; Chailapakul, O. Pop-up paper electrochemical device for label-free hepatitis B virus DNA detection. Sens. Actuators B Chem. 2020, 316. [CrossRef]

109. Ruiz-Vega, G.; Arias-Alpízar, K.; de la Serna, E.; Borgheti-Cardoso, L.N.; Sulleiro, E.; Molina, I.; Fernàndez-Busquets, X.; Sánchez-Montalvá, A.; del Campo, F.J.; Baldrich, E. Electrochemical POC device for fast malaria quantitative diagnosis in whole blood by using magnetic beads, Poly-HRP and microfluidic paper electrodes. Biosens. Bioelectron. 2020, 150. [CrossRef]

110. Farkhondeh, T.; Forouzanfar, F.; Roshanravan, B.; Samarghandian, S. Curcumin effect on non-amyloidogenic pathway for preventing alzheimer's disease. Biointerface Res. Appl. Chem. 2019, 9, 4085-4089. [CrossRef]

111. Moya-Alvarado, G.; Gershoni-Emek, N.; Perlson, E.; Bronfman, F.C. Neurodegeneration and Alzheimer's disease (AD). What Can Proteomics Tell Us About the Alzheimer's Brain? Mol. Cell. Proteom. 2016, 15, 409-425. [CrossRef] [PubMed]

112. Blennow, K.; Zetterberg, H. Biomarkers for Alzheimer's disease: Current status and prospects for the future. J. Intern. Med. 2018, 284, 643-663. [CrossRef] [PubMed]

113. Zetterberg, H.; Blennow, K. From Cerebrospinal Fluid to Blood: The Third Wave of Fluid Biomarkers for Alzheimer's Disease. J. Alzheimer Dis. 2018, 64, S271-S279. [CrossRef] [PubMed]

114. Teunissen, C.E.; Verheul, C.; Willemse, E.A.J. Chapter 1-The use of cerebrospinal fluid in biomarker studies. In Handbook of Clinical Neurology; Deisenhammer, F., Teunissen, C.E., Tumani, H., Eds.; Elsevier: Amsterdam, The Netherlands, 2018; Volume 146, pp. 3-20.

115. Altuna-Azkargorta, M.; Mendioroz-Iriarte, M. Blood biomarkers in Alzheimer's disease. Neurología 2020. [CrossRef]

116. Hampel, H.; O’Bryant, S.E.; Molinuevo, J.L.; Zetterberg, H.; Masters, C.L.; Lista, S.; Kiddle, S.J.; Batrla, R.; Blennow, K. Blood-based biomarkers for Alzheimer disease: Mapping the road to the clinic. Nat. Rev. Neurol. 2018, 14, 639-652. [CrossRef] [PubMed]

117. Zetterberg, H.; Burnham, S.C. Blood-based molecular biomarkers for Alzheimer's disease. Mol. Brain 2019, 12, 26. [CrossRef]

118. Gabelli, C. Blood and cerebrospinal fluid biomarkers for Alzheimer's disease. J. Lab. Precis. Med. 2020, 5. [CrossRef]

119. Toombs, J.; Zetterberg, H. In the blood: Biomarkers for amyloid pathology and neurodegeneration in Alzheimer's disease. Brain Commun. 2020, 2. [CrossRef]

120. O’Bryant, S.E. Blood Biomarkers for Use in Alzheimer Disease-Moving From "If" to "How?". JAMA Neurol. 2019, 76, 1009-1010. [CrossRef]

121. Mattsson, N.; Cullen, N.C.; Andreasson, U.; Zetterberg, H.; Blennow, K. Association Between Longitudinal Plasma Neurofilament Light and Neurodegeneration in Patients with Alzheimer Disease. JAMA Neurol. 2019, 76, 791-799. [CrossRef]

122. Weston, P.S.J.; Poole, T.; Ryan, N.S.; Nair, A.; Liang, Y.; Macpherson, K.; Druyeh, R.; Malone, I.B.; Ahsan, R.L.; Pemberton, H.; et al. Serum neurofilament light in familial Alzheimer disease. J. Neurol. 2017, 89, 2167-2175. [CrossRef]

123. Ashton, N.J.; Ide, M.; Zetterberg, H.; Blennow, K. Salivary Biomarkers for Alzheimer's Disease and Related Disorders. Neurol. Ther. 2019, 8, 83-94. [CrossRef] [PubMed]

124. Farah, R.; Haraty, H.; Salame, Z.; Fares, Y.; Ojcius, D.M.; Said Sadier, N. Salivary biomarkers for the diagnosis and monitoring of neurological diseases. Biomed. J. 2018, 41, 63-87. [CrossRef] [PubMed]

125. González-Sánchez, M.; Bartolome, F.; Antequera, D.; Puertas-Martín, V.; González, P.; Gómez-Grande, A.; Llamas-Velasco, S.; San Martín, A.H.; Pérez-Martínez, D.; Villarejo-Galende, A. Decreased salivary lactoferrin levels are specific to Alzheimer's disease. Res. Square 2020. [CrossRef] [PubMed]

126. Falcon, C.; Monté-Rubio, G.C.; Grau-Rivera, O.; Suárez-Calvet, M.; Sánchez-Valle, R.; Rami, L.; Bosch, B.; Haass, C.; Gispert, J.D.; Molinuevo, J.L. CSF glial biomarkers YKL40 and sTREM2 are associated with longitudinal volume and diffusivity changes in cognitively unimpaired individuals. NeuroImage Clin. 2019, 23, 101801. [CrossRef] [PubMed] 
127. Zhong, L.; Xu, Y.; Zhuo, R.; Wang, T.; Wang, K.; Huang, R.; Wang, D.; Gao, Y.; Zhu, Y.; Sheng, X.; et al. Soluble TREM2 ameliorates pathological phenotypes by modulating microglial functions in an Alzheimer's disease model. Nat. Commun. 2019, 10, 1365. [CrossRef] [PubMed]

128. Llorens, F.; Thüne, K.; Tahir, W.; Kanata, E.; Diaz-Lucena, D.; Xanthopoulos, K.; Kovatsi, E.; Pleschka, C.; Garcia-Esparcia, P.; Schmitz, M.; et al. YKL-40 in the brain and cerebrospinal fluid of neurodegenerative dementias. Mol. Neurodegener. 2017, 12, 83. [CrossRef]

129. Bălașa, A.F.; Chircov, C.; Grumezescu, A.M. Marine Biocompounds for Neuroprotection-A Review. Mar. Drugs 2020, 18, 290. [CrossRef]

130. Bălașa, A.; Șerban, G.; Chinezu, R.; Hurghiș, C.; Tămaș, F.; Manu, D. The Involvement of Exosomes in Glioblastoma Development, Diagnosis, Prognosis, and Treatment. Brain Sci. 2020, 10, 553. [CrossRef]

131. Balasa, R.; Barcutean, L.; Balasa, A.; Motataianu, A.; Roman-Filip, C.; Manu, D. The action of TH17 cells on blood brain barrier in multiple sclerosis and experimental autoimmune encephalomyelitis. Hum. Immunol. 2020, 81, 237-243. [CrossRef]

132. Bălaşa, R.; Maier, S.; Bajko, Z.; Motataianu, A.; Crişan, A.; Bălaşa, A. Longitudinally extensive transverse myelitis in neuromyelitis optica: A prospective study of 13 Caucasian patients and literature review. Acta Neurol. Belg. 2015, 115, 635-642. [CrossRef]

133. Brazaca, L.C.; Sampaio, I.; Zucolotto, V.; Janegitz, B.C. Applications of biosensors in Alzheimer's disease diagnosis. Talanta 2020, 210, 120644. [CrossRef] [PubMed]

134. Shui, B.; Tao, D.; Florea, A.; Cheng, J.; Zhao, Q.; Gu, Y.; Li, W.; Jaffrezic-Renault, N.; Mei, Y.; Guo, Z. Biosensors for Alzheimer's disease biomarker detection: A review. Biochimie 2018, 147, 13-24. [CrossRef] [PubMed]

135. Tarutani, A.; Hasegawa, M. Chapter Eighteen-Prion-like propagation of $\alpha$-synuclein in neurodegenerative diseases. In Progress in Molecular Biology and Translational Science; Teplow, D.B., Ed.; Academic Press: Cambridge, MA, USA, 2019; Volume 168, pp. 323-348.

136. Meade, R.M.; Fairlie, D.P.; Mason, J.M. Alpha-synuclein structure and Parkinson's disease-Lessons and emerging principles. Mol. Neurodegener. 2019, 14, 29. [CrossRef] [PubMed]

137. Østergaard, F.G.; Himmelberg, M.M.; Laursen, B.; Siebner, H.R.; Wade, A.R.; Christensen, K.V. Classification of $\alpha$-synuclein-induced changes in the AAV $\alpha$-synuclein rat model of Parkinson's disease using electrophysiological measurements of visual processing. Sci. Rep. 2020, 10, 11869. [CrossRef] [PubMed]

138. Mahul-Mellier, A.-L.; Burtscher, J.; Maharjan, N.; Weerens, L.; Croisier, M.; Kuttler, F.; Leleu, M.; Knott, G.W.; Lashuel, H.A. The process of Lewy body formation, rather than simply $\alpha$-synuclein fibrillization, is one of the major drivers of neurodegeneration. Proc. Natl. Acad. Sci. USA 2020, 117, 4971-4982. [CrossRef] [PubMed]

139. Ricci, S.; Casalini, S.; Parkula, V.; Selvaraj, M.; Saygin, G.D.; Greco, P.; Biscarini, F.; Mas-Torrent, M. Label-free immunodetection of $\alpha$-synuclein by using a microfluidics coplanar electrolyte-gated organic field-effect transistor. Biosens. Bioelectron. 2020, 167. [CrossRef] [PubMed]

140. Song, C.; Deng, P.; Que, L. Rapid multiplexed detection of beta-amyloid and total-tau as biomarkers for Alzheimer's disease in cerebrospinal fluid. Nanomedicine 2018, 14, 1845-1852. [CrossRef]

141. Antunes, A.P.; Schiefecker, A.J.; Beer, R.; Pfausler, B.; Sohm, F.; Fischer, M.; Dietmann, A.; Lackner, P.; Hackl, W.O.; Ndayisaba, J.-P.; et al. Higher brain extracellular potassium is associated with brain metabolic distress and poor outcome after aneurysmal subarachnoid hemorrhage. Crit. Care 2014, 18, R119. [CrossRef]

142. Liu, J.; Li, F.; Wang, Y.; Pan, L.; Lin, P.; Zhang, B.; Zheng, Y.; Xu, Y.; Liao, H.; Ko, G.; et al. A sensitive and specific nanosensor for monitoring extracellular potassium levels in the brain. Nat. Nanotechnol. 2020, 15, 321-330. [CrossRef]

143. Serafín, V.; Gamella, M.; Pedrero, M.; Montero-Calle, A.; Razzino, C.A.; Yáñez-Sedeño, P.; Barderas, R.; Campuzano, S.; Pingarrón, J.M. Enlightening the advancements in electrochemical bioanalysis for the diagnosis of Alzheimer's disease and other neurodegenerative disorders. J. Pharm. Biomed. Anal. 2020, 189, 113437. [CrossRef]

Sample Availability: Samples of the compounds are not available from the authors.

Publisher's Note: MDPI stays neutral with regard to jurisdictional claims in published maps and institutional affiliations.

(C) 2020 by the authors. Licensee MDPI, Basel, Switzerland. This article is an open access article distributed under the terms and conditions of the Creative Commons Attribution (CC BY) license (http://creativecommons.org/licenses/by/4.0/). 